\title{
MOŁDAWSKIE SPOŁECZEŃSTWO OBYWATELSKIE W INTEGRACJI EUROPEJSKIEJ
}

\author{
Jakub Lachert \\ Wydział Dziennikarstwa i Nauk Politycznych, Uniwersytet Warszawski \\ e-mail: Kuba-lachert@wp.pl
}

\begin{abstract}
Streszczenie: Artykuł przedstawia wybrane elementy sytuacji społeczeństwa obywatelskiego w Mołdawii. Podstawową tezą artykułu jest stwierdzenie, że organizacje społeczeństwa obywatelskiego w Mołdawii muszą poprawić swoją komunikację ze społeczeństwem. Uzależnienie mołdawskich NGO od pomocy finansowej od donatorów z UE może tworzyć stosunki zleceniodawca/ agent. NGO powinny uwzględniać potrzeby społeczeństwa i stymulować rząd na ścieżce proeuropejskiej. Autor dowodzi, że komunikacja między administracją publiczną i społeczeństwem obywatelskim ma kluczowe znaczenie w procesie integracji z UE.
\end{abstract}

Słowa kluczowe: społeczeństwo obywatelskie, Mołdawia, organizacje pozarządowe, Principal/ Agent Theory

\section{WSTĘP}

Przedmiotem analizy w niniejszym artykule jest rozwój społeczeństwa obywatelskiego w Mołdawii, państwa powstałego w 1991 roku w wyniku rozpadu Związku Radzieckiego. Nowo tworzone struktury społeczeństwa obywatelskiego napotykają w Mołdawii na liczne trudności, które mają zarówno wewnętrzny, jak i zewnętrzny charakter. Do najważniejszych czynników wewnętrznych należą przede wszystkim: społeczna bierność i deficyt pogłębionej komunikacji na linii władza-organizacje pozarządowe, natomiast czynnikiem zewnętrznym jest promowanie idei społeczeństwa obywatelskiego w ramach integracji europejskiej.

W roku 2009 w Mołdawii nastąpiły zmiany polityczne, zapoczątkowujące tak zwaną twitterową rewolucję ${ }^{1}$. Nowe rządy, ustanowione przez partie proeuropej-

1 Demonstracje w kwietniu 2009 roku, w których trakcie uczestnicy protestowali przeciwko sfałszowaniu wyborów i wygranej Partii Komunistów Republiki Mołdawii. Demonstranci zwoływali się za pomocą serwisów społecznościowych, w tym Twittera, stąd nazwa tych wydarzeń. 
skie, określiły jako cel nawiązanie bliskich więzów pomiędzy Mołdawią a Unią Europejską (UE), a także zreformowanie państwa w duchu demokracji zachodnich. Budowa silnego społeczeństwa obywatelskiego i dialog pomiędzy władzą a społeczeństwem stały się jednym z kluczowych kryteriów zbliżenia Mołdawii do UE.

Mołdawia musiała budować instytucje demokratyczne od podstaw, ponieważ przed odzyskaniem niepodległości, w żadnym okresie historii nowożytnej, nie posiadała państwowości de iure. Historycznie terytorium współczesnej Mołdawii stanowiło sporny obszar pomiędzy Imperium Rosyjskim a tworzącą się w XIX wieku Rumunią. Późniejsze włączenie Mołdawii w skład Związku Radzieckiego doprowadziło do masowego napływu ludności rosyjskojęzycznej na tereny pomiędzy Prutem a Dniestrem. Wywołało to podziały społeczne pomiędzy ludnością napływową a rdzenną ludnością rumuńskojęzyczną. Upraszczając, można stwierdzić, że większość społeczności rumuńskojęzycznej zamieszkującej na tym terytorium stanowiła ludność wiejska, natomiast rosyjskojęzyczna część społeczeństwa stanowiła kadrę urzędniczą zamieszkującą większe ośrodki miejskie. Trudności w budowaniu społeczeństwa obywatelskiego w Mołdawii wynikają, z jednej strony, z postsowieckiej spuścizny, a z drugiej, z braku miejskiej klasy średniej. Mołdawia w okresie Związku Radzieckiego była ukierunkowana na produkcję rolną, stąd dużo większy procent ludności niż w innych europejskich krajach, był zatrudniony w tym sektorze.

Aspiracje części społeczeństwa mołdawskiego związane są z przystąpieniem do Unii Europejskiej, co wiąże się z przyjęciem nie tylko dorobku prawnego tej organizacji, ale również pewnych norm społecznych wypracowywanych w społeczeństwach zachodnich. Trudność we wdrożeniu tych norm, w takich państwach jak Mołdawia, związana jest, przede wszystkim, ze spuścizną władzy radzieckiej, która promowała działalność obywateli w projektach wyznaczonych przez partię komunistyczną, a nie współpracę obywateli na lokalnym poziomie, stanowiącą istotę społeczeństwa obywatelskiego.

Celem tego artykułu jest udzielenie odpowiedzi na następujące pytania: Dlaczego $\mathrm{w}$ społeczeństwie mołdawskim istnieją trudności przy tworzeniu społeczeństwa obywatelskiego? Jakie zmiany są możliwe, aby zaistniał silny czynnik społeczny, który będzie stał na straży reform oraz przyczyniał się do aktywizacji społeczeństwa w życiu publicznym?

Hipotetycznie wśród największych trudności w aktywizacji społeczeństwa obywatelskiego można wymienić nieufność Mołdawian wobec życia politycznego w swoim kraju oraz brak odpowiednich środków finansowych przeznaczonych na ten cel, a także podziały etniczne. Budowa świadomego społeczeństwa obywatelskiego jest kluczowym czynnikiem wprowadzania reform politycznych i gospodarczych. Dokonanie pełnej transformacji ustrojowej w Mołdawii nie jest też możliwe bez osiągnięcia konsensusu pomiędzy najważniejszymi grupami narodowościowymi. Obecne obawy części społeczeństwa, dotyczące integracji europejskiej, są wynikiem, w głównej mierze, braku odpowiedniej informacji i wiedzy co do konsekwencji zbliżenia ze strukturami UE. Dotyczy to zarówno 
przeciwników integracji, uważających, że jest to forma kolonizacji ze strony Brukseli, jak i części zwolenników, dla których wejście do UE wiąże się z pewnym utopijnym obrazem automatycznego wejścia do grupy państw zamożnych. Trzeba pamiętać, że chociaż Mołdawia nie jest członkiem UE, to po podpisaniu 27 czerwca 2014 umowy stowarzyszeniowej z Unią Europejską, zawierającej postanowienia o utworzeniu pogłębionej i kompleksowej strefy wolnego handlu (the Deep and Comprehensive Free Trade Area - DCFTA), zaistniało wiele różnych formalnych narzędzi umożliwiających ściślejszą współpracę stron.

\section{UJĘCIE TEORETYCZNE}

Proces budowy społeczeństwa obywatelskiego w Mołdawii można rozpatrywać w ramach teorii PAT (Principal/Agent Theory) [Ruszkowski 2008]. W tym artykule chciałbym naświetlić zależności tzw. trzeciego sektora w Mołdawii od zachodnioeuropejskich mocodawców, czyli rządów państw UE, fundacji oraz Komisji Europejskiej, finansujących mołdawskie think tanki, działające na rzecz pogłębiania integracji Mołdawii z UE, np. Expert-Grup, Institute for Development and Social Initiatives - IDIS "Viitorul", The Foreign Policy Association of Moldova (APE), The Association for Participatory Democracy ADEPT . Zgodnie z zadeklarowanym podejściem teoretycznym, podmioty wspierające organizacje pozarządowe dysponują narzędziami do prowadzenia swojej polityki, natomiast wykonawcą w tym przypadku są organizacje pozarządowe, które zyskują wsparcie finansowe potrzebne do realizacji projektów.

Chociaż organizacje pozarządowe nie posiadają żadnego formalnego statusu do prowadzenia polityki w zakresie integracji Mołdawii z UE, to mogą pełnić rolę niezależnego agenta zgodnie $\mathrm{z}$ teorią PAT. Think tanki finansowane przez źródła zagraniczne otrzymują projekty do wykonania, tworzące ramy współpracy Mołdawii z UE. Mołdawskie organizacje pozarządowe finansowane ze źródeł unijnych są w pewnym zakresie pośrednikiem w kontaktach UE z rządem Mołdawii. Dodatkowo część funduszy przyznawanych mołdawskim ministerstwom odpowiedzialnym za integrację europejską jest przekazywana think tankom na realizację kolejnych projektów. W tym przypadku, zgodnie z teorią PAT, to rząd mołdawski staje się zleceniodawcą, a organizacje pozarządowe - wykonawcami. Przenoszenie odpowiedzialności za realizację projektów na trzeci sektor jest korzystne dla strony rządowej, ponieważ otrzymuje ona wsparcie merytoryczne, zarazem jednak prowadzi do dużej autonomii działań think tanków. Według teorii PAT, agent posiadający większy potencjał merytoryczny niż mocodawca zyskuje dużą autonomię działań [Ruszkowski 2008].

Tego typu zależności prowadzą do marginalizacji czynnika społecznego. Organizacje pozarządowe w takim systemie są jedynie wykonawcami poleceń swoich zwierzchników i nie potrzebują konsultacji społecznych. Stanowi to podstawowy problem - wiarygodności tych organizacji w społeczeństwie mołdawskim. 
Głównym celem Komisji Europejskiej we wspieraniu społeczeństwa obywatelskiego w Mołdawii jest realizacja umowy stowarzyszeniowej. Projekty finansowane przez Komisję Europejską przeznaczone są na szkolenia pracowników think tanków oraz na realizację licznych projektów mających na celu wspomaganie rządu we wprowadzaniu proeuropejskich reform. Poszczególne organizacje, otrzymując finansowanie na konkretne projekty, wchodzą w sieć zależności od swojego donatora. W przypadku współpracy instytucji UE ze stroną rządową stosunki budowane są raczej na zasadzie partnerstwa. Realizacja zobowiązań wynikających z podpisania umowy stowarzyszeniowej jest warunkowana wieloma czynnikami, na które UE nie ma pełnego wpływu, na przykład dominującymi nastrojami politycznymi w społeczeństwie. Rolą mołdawskich think tanków, z perspektywy UE, jest tworzenie wokół rządu proeuropejskiego zaplecza intelektualnego. Jednak w tej strategii nie jest wystarczająco uwzględniony czynnik społeczny. Większość społeczeństwa nie rozumie, na czym polega działalność NGO-sów. Jednocześnie niewystarczająca jest komunikacja na linii obywatele-NGO-rząd, co utrudnia budowanie społeczeństwa obywatelskiego w Mołdawii.

\section{DZIAŁALNOŚĆ SPOŁECZEŃSTWA OBYWATELSKIEGO W MOŁDAWII}

W Mołdawii zarejestrowanych jest ponad 7000 organizacji pożytku publicznego, ale jedynie $25 \% \mathrm{z}$ nich prowadziło jakieś projekty w ostatnich trzech latach (raport z 2015 roku) [Chiriac, Tugui, 2014]. Większość z tych organizacji (50\%) zajmuje się szkoleniami i treningami zawodowymi, natomiast najmniejszy odsetek $(16,9 \%)$ - kulturą [Chiriac, Tugui, 2014]. Jedynie 10\% instytucji pozarządowych zajmuje się takimi dziedzinami jak: środowisko, związki zawodowe, doradztwo przedsiębiorstwom, natomiast aż $60 \%$ deklaruje swoje zainteresowanie sprawami związanymi z polityką zagraniczną, integracją z Unią Europejską, rolnictwem oraz prawami człowieka [Chiriac, Tugui, 2014]. Pozostałe pola działalności to: media, doradztwo prawne oraz przeciwdziałanie korupcji. Spośród 22 organizacji pozarządowych zarejestrowanych w separatystycznym Naddniestrzu większość deklaruje swoje zainteresowanie kwestiami pomocy społecznej $(63,6 \%)$ oraz kwestiami związanymi z młodzieżą (50\%).

\section{POSTAWY MOŁDAWIAN A SPOŁECZEŃSTWO OBYWATELSKIE}

Mołdawia, podobnie jak pozostałe republiki postradzieckie, zmaga się z trudnościami wynikającymi z transformacji ustrojowej. Wśród obywateli Mołdawii ograniczone są postawy obywatelskie, które mogłyby doprowadzić do szerszej partycypacji w lokalnych inicjatywach. Działalność organizacji pozarządowych nie posiada szerokiego poparcia społecznego, jest to wynik braku zaufania obywateli do podmiotów finansowanych ze środków zagranicznych. 
Stąd część społeczeństwa mołdawskiego, wrażliwego w kwestiach suwerenności, obawia się zewnętrznych ingerencji prowadzących do utraty niezależności. Zarazem organizacje pozarządowe mają „elitarny” charakter, jedynie $4 \%$ społeczeństwa partycypuje w ich inicjatywach. Niski procent aktywności społeczeństwa przekłada się również na zaufanie do organizacji pozarządowych, które wynosi jedynie $20 \%$, podczas gdy aż $80 \%$ Mołdawian ufa cerkwi prawosławnej [Chiriac, Tugui, 2014] .

Mołdawskie społeczeństwo obywatelskie stanowiło najistotniejszy element rewolucji z 2009 roku, w której trakcie oddolny ruch obywatelski doprowadził do odsunięcia od władzy Partii Komunistów Republiki Mołdawii. Chociaż zmiany polityczne doprowadziły do głębszej współpracy z Unią Europejską na poziomie administracyjnym, to nie przyczyniły się do przemian w relacjach obywateli z państwem. Większość obywateli podchodzi nieufnie do rozwiązań proponowanych przez rząd, jednocześnie nie próbuje zaktywizować się w ruchach obywatelskich, stanowiących niezależny głos w dyskusji na temat przyszłości kraju. Warunkiem koniecznym rozwoju społeczeństwa obywatelskiego jest zbudowanie państwa w oparciu o zasady prawa i przejrzystego podziału władzy. Dodatkowym problemem jest brak organizacji pozarządowych poza dużymi miastami, takimi jak: Kiszyniów, Bielce, Cahul. Mołdawia jest państwem, w którym odsetek ludności zamieszkałej na wsi należy do największych w całej Europie i wynosi $53 \%$ [Worldstat Info]. Nie przekłada się to jednak na aktywność w organizacjach pozarządowych, reprezentujących interesy tej grupy społecznej.

\section{SPOŁECZEŃSTWO WOBEC PODZIAŁÓW ETNICZNYCH}

Istotnym elementem ograniczającym możliwość stworzenia spójnego społeczeństwa obywatelskiego jest głęboki podział co do wizji dalszego rozwoju państwa. Część obywateli pochodzenia rosyjskiego lub używającego tego języka obawia się rozwoju współpracy z Unią Europejską, a tym samym z Rumunią, ponieważ może to, ich zdaniem, doprowadzić do sytuacji „spychania” ludności nierumuńskojęzycznej na margines życia społecznego. Część społeczeństwa mołdawskiego wspierającego integrację ze strukturami rosyjskimi nie podziela wspólnych wartości z resztą społeczeństwa, które jest skłonne do zaakceptowania demokracji liberalnej [Lupusor 2015]. Rosyjskojęzyczni obywatele Mołdawii czerpią swoją wiedzę o świecie głównie z rosyjskich mediów, przedstawiających integrację europejską Mołdawii jako próbę kolonizacji tego państwa przez Rumunię, państwo członkowskie UE. Dodatkowym argumentem przeciwników integracji z UE jest obawa przed utratą rosyjskiego rynku pracy, na którym zatrudnionych jest średnio pół miliona obywateli mołdawskich [Całus 2015]. W przypadku przystąpienia Mołdawii do Unii Europejskiej dostęp do zatrudnienia w Moskwie czy Sankt Petersburgu może być ograniczony. Stąd bierze się również niechęć tej części społeczeństwa do angażowania się w projekty mające na celu 
wprowadzenie odpowiednich reform dostosowujących standardy w administracji i prawodawstwie do wymogów Unii Europejskiej. Oznacza to pewnego rodzaju przekonanie, że wszelkie działania ośrodków pozarządowych mają na celu integrację europejską, a nie polepszenie jakości życia w kraju, który, w ich przekonaniu, zależy od pomocy finansowej Rosji i niskich cen za gaz i ropę naftową importowaną ze wschodu.

\section{FINANSOWANIE TRZECIEGO SEKTORA W MOŁDAWII}

Organizacje pozarządowe w Mołdawii zmagają się z brakiem środków finansowych, co powoduje, że dobrze wyszkoleni pracownicy szukają zatrudnienia raczej $\mathrm{w}$ mediach oraz $\mathrm{w}$ administracji państwowej, a przede wszystkim w organizacjach międzynarodowych. Ze strony państwa wsparcie finansowe dla organizacji pozarządowych ogranicza się do zwolnień z podatku dochodowego, natomiast nie istnieją żadne państwowe dotacje dla nich. Wyjątkiem są jedynie granty specjalnego przeznaczenia oferowane przez trzy ministerstwa: ds. młodzieży i sportu, środowiska oraz kultury. Brakuje programów przeznaczonych na projekty regionalne, w tym w autonomicznej Gagauzji. Większość projektów, zasilanych przez granty ministerialne lub finansowane przez źródła zagraniczne, trafia do dużych think tanków z Kiszyniowa.

Dodatkowo działacze niezależnych organizacji pozarządowych w Mołdawii prowadzą swoje działania jako wolontariusze, co uniemożliwia im pełne zaangażowanie. Ta sytuacja prowadzi do rezygnacji dobrze wykształconych ludzi z udziału w kształtowaniu społeczeństwa obywatelskiego. W zamian za to mołdawskie elity intelektualne wybierają zatrudnienie w międzynarodowych organizacjach. Kolejnym utrudnieniem w prowadzeniu organizacji pozarządowej jest brak wymiany informacji i danych z administracją publiczną, prowadzi to również po wielekroć do dublowania swoich działań.

\section{PODSUMOWANIE}

Występowanie zależności pomiędzy mołdawskimi think tankami i innymi organizacjami pozarządowymi a zewnętrznymi źródłami finansowania (państwa członkowskie UE, Komisja Europejska) utrudnia budowanie relacji między nimi a administracją państwową. Organy państwowe bowiem mogą traktować NGO-sy jako pewnego rodzaju ciało kontrolne, a nie partnera do budowania transparentnych struktur państwowych.

Społeczeństwo obywatelskie w Mołdawii potrzebuje aktywizacji i współpracy ze stroną rządową, ponieważ jedynie koordynacja działań i informowanie społeczeństwa o nich mogą prowadzić do jego konsolidacji. Organizacje pozarządowe nie napotykają ze strony państwa żadnych trudności w prowadzeniu 
działalności, zasady ich funkcjonowania są chronione przez prawo, jednak brak pomocy finansowej ze strony administracji publicznej ogranicza szersze możliwości ich działania. Istotnym elementem powinna być również promocja działań organizacji pozarządowych wśród społeczeństwa, które w niewielkim stopniu zdaje sobie sprawę z ich dokonań, co przekłada się również na partycypację pojedynczych obywateli w działalności think tanków. Zdecydowanie większa część (83\%) think tanków nie otrzymała nigdy żadnej prywatnej dotacji [Lutsevych 2013]. Organizacje pozarządowe, które działają na rzecz obywateli, nie są odpowiednio promowane w mediach, dlatego ich działania nie są powszechnie znane wśród obywateli. Jednak największym wyzwaniem zarówno dla think tanków, jak i dla administracji rządowej, jest zdobycie zaufania obywateli. W obecnej sytuacji społeczeństwo, w większości ukształtowane w okresie sowieckim, nie ufa swoim władzom, które są, w jego odczuciu, skorumpowane. Władza radziecka próbowała również wyeliminować krytyczne myślenie i narzucała swoje projekty bez uprzednich konsultacji. Stworzenie nowoczesnego społeczeństwa obywatelskiego w Mołdawii wymaga zatem wyeliminowania spuścizny władzy radzieckiej.

Głównym partnerem w dyskusji o reformowaniu państwa dla trzeciego sektora powinni być obywatele, a nie tylko sponsorzy ich działań. Mołdawianie nie są odpowiednio informowani przez media państwowe o działalności mołdawskich think tanków. Organizacje te powinny skierować swoją działalność na projekty służące promocji idei integracji europejskiej oraz próbować aktywizować lokalną społeczność poprzez konsultacje społeczne.

Korzystne dla rozwoju społeczeństwa obywatelskiego byłoby tworzenie think tanków finansowanych ze środków państwowych, które stanowiłyby zaplecze intelektualne rządu, a nie sui generis ,ciało kontrolne” finansowane ze środków zagranicznych.

\section{WYKAZ PIŚMIENNICTWA:}

1. Całus K., Co po Wi(l)nie?, Nowa Europa Wschodnia, 8 września 2015.

2. Chiriac L., Tugui E., 2014. Civil society organizations from Moldova: development, Sustainability and participation in policy dialogue, Konrad Adenaur Stiftung.

3. Lupusor A., 2015. Republic of Moldova 2015 - State of the country Report, Expert-Grup.

4. Lutsevych O., 2013. How to finish a revolution: Civil society and Democracy in Georgia, Moldova and Ukraine, Chatam House.

5. Ruszkowski J., 2008: Zastosowanie Teorii PAT do analizy wielopoziomowego zarządzania w Unii Europejskiej. Studia Europejskie 2008. 4.

6. Worldstat Info, Map Europe by the population in rural areas, http://en.worldstat.info/Europe/ List_of_countries_by_Population_in_rural_areas. 


\title{
MOLDOVAN CIVIL SOCIETY IN EUROPEAN INTEGRATION
}

\begin{abstract}
The fundamental thesis of this paper is that Moldovan civil society needs to improve its communication with society. The dependence of Moldovan NGOs on financial aid from EU donors could create a Principal/Agent relationship. NGOs should respect the needs of society and stimulate the government on a pro-European path. The author proves that communication between public administration and civil society is crucial in the process of integration with the EU.
\end{abstract}

Key words: civil society, Moldova, PAT, think tanks 